it is fascinating that in the years of his publication of Drum-Taps (1865) and Sequel to Drum-Taps (1865-1866), Whitman was attentive to popular ballads being sung about the Civil War. As Whitman created his own artistic reaction to the devastation, he was touched by an old and simple ballad composed from the perspective of one left at home. Perhaps Walt Whitman, who gave so much affection and care to wounded soldiers as he nursed them during the war, identified with the lonely voice of "Johnny is Gone for a Soldier," who pines for an absent lover and is overcome with grief.

University of Nebraska-Lincoln

ANDREW W. JEWELL

\title{
NOTES
}

1 Arthur Golden, “'I'll Trace This Garden': A Note on a Non-Whitman Attribution," Walt Whitman Quarterly Review 2 (Winter 1985), 28.

2 Golden, 28n.

3 The song, in altered forms, has been dated as far back as the early eighteenth century, as an Irish folk song entitled "Shule Aroon" (William Cole, ed., Folk Songs of England, Ireland, Scotland, and Wales, arranged by Norman Monath, drawings by Edward Ardizzone [Garden City, New York: Doubleday \& Company, Inc., 1961], 64). It was known with the title "Johnny is Gone for a Soldier" in the United States during the American Revolution (John A. Lomax and Alan Lomax, eds., Folk Song U.S.A.: The 111 Best American Ballads, music eds., Charles Seeger and Ruth Crawford Seeger [New York: Duell, Sloan, and Pearce, 1947], 112).

4 Blodgett and Bradley date "[I'll Trace This Garden]" c.1865, due to its composition on letterhead from the Attorney-General's Office, Washington, where Whitman began working July 1, 1865 (Harold W. Blodgett and Sculley Bradley, eds., Leaves of Grass, Comprehensive Reader's Edition [New York: New York University Press, 1965], 697n).

5 "Johnny is Gone for a Soldier" (New York: H. DeMarsan, [1862?]), Cornell University, Kroch Library Rare and Manuscript Collections, no. 35 in a volume lettered "Civil War Pamphlets, 1861-1867."

6 Whitman's manuscript appears in the Feinberg-Whitman Collection, Library of Congress, Manuscript Division.

7 Martin G. Murray, "'Pete the Great': A Biography of Peter Doyle," Walt Whitman Quarterly Review 12 (Summer 1994), 19.

8 Walt Whitman, Prose Works 1892, ed. Floyd Stovall (New York: New York University Press, 1963), 1:57-58.

\section{WHITMAN AND THE AFTERLIFE: "SPARKLES FROM THE WHEEL"}

When D. H. Lawrence irreverently described Walt Whitman as "a very great post mortem poet," he touched on what would become a painful nerve for later critics. Whitman's abiding interest in-some would say his peculiar pre- 
occupation with - death has for decades puzzled, even annoyed, many of his twentieth-century readers. Some detect slight inconsistencies in the poet's view of death, but on the whole they find a coherent concept of humanity's passage from this world to something unknown that somehow completes or fulfills the present version of our life. ${ }^{2}$ Others reach for more exotic explanations of Whitman's alleged "perverse attraction to death," including the claim that he wished for "a heroic death that [would] liberate him from the death-in-life which he associate[d] with erotic bereavement and with sexual repression." 3 There are those, as well, who simply deny the poet's affirmation of death; for them, Whitman's "shouted pronouncements on immortality bespeak not the exultation of the man assured that he will never die, but the anxiety of the man terrified that he will."

It is like a breath of fresh air to turn to the levelheaded entry on death in a recent Whitman encyclopedia. This entry addresses such cultural matters as the high mortality rates and the requisite commonplace deathbed watches typical of the poet's day. ${ }^{5}$ The entry could have also reported the American nineteenth-century obsession with both premature burial and spiritualism, ${ }^{6}$ or the core of morbidity in sentimental tradition, ${ }^{7}$ or even the monumental impact of the carnage of the Civil War on the national psyche. In short, we can conclude, Whitman clearly sought to ally what he perceived to be a widespread cultural anxiety concerning mortality. And, as the verse quotations cited in the encyclopedia entry effectively suggest, Whitman countered such cultural fear with promises of immortality. As we will see, he specifically believed in a life-process in which each human self advances incrementally and asymptotically (in Hegelian manner) toward some undefined perfection.

This notion, influenced by Asian thought, is thoroughly Transcendentalist. In $A$ Week on the Concord and Merrimack Rivers (1849), for instance, Thoreau images the progress of life (at once material and spiritual) as a succession of door openings. Death itself is like leaving our home and going outdoors, where nature in turn becomes a home with a doorway to still another mansion-like exterior. ${ }^{8}$ This ad infinitum process of leaving one house to enter an "outside" that is always another and better home is a kindred version of the asymptotic advancement suggested in Whitman's related claims that death is a "solemn immortal birth" and that "the dead advance as much as the living advance."

Attempts to ascertain Whitman's understanding of the afterlife have generally pieced together clues from various lines from his works. But "Sparkles from the Wheel," a poem that first appeared in Leaves of Grass in 1871, distinctively focuses on the issue. Although this poem is frequently anthologized, it has resisted critical consensus and apparently has not been read as a testament to Whitman's concept of an afterlife.

Commentary on "Sparkles from the Wheel" (389-90) has primarily emphasized the knife-grinder, who has been said to represent a Jehovah figure, the creative artist, and the poet himself. ${ }^{10}$ It is important to note, however, that the title and the refrain of the poem direct our attention finally to the treadle wheel and its sparkles rather than to any particular individual in the scene. We will return to this point, but it is nonetheless useful to commence with the figure of the knife-grinder.

The fact that the knife-grinder is described as an "old man" is noteworthy. He marks the end of the human life cycle. In fact, however, people in 
various stages of aging populate the scene. Most obvious are "the attentive, quiet children." Least obvious are their parents and other adults who, in specific contrast to the settled watching children, comprise the "city's ceaseless crowd." These adults "move on the livelong day"-that is, they engage in the welter of life-transactions, and in the process they are moving along all phases comprising the transit of lived time between childhood and old age. "The livelong day" alludes to the triadic pattern of morning, noon and night-traditional symbols for representing the cycle of a human life through childhood, adulthood and old age.

But in "Sparkles from the Wheel" there is, as well, another figure who does not belong to any of these three stages. It is the speaker of the poem who describes himself as "a phantom curiously floating." We should take him at his word, something critics have been reluctant to do, when he says he is a phantom, a ghost. Note that he floats, that he is "effusing and fluid." $\mathrm{He}$ is non-corporeal, an experience so new to him that he designates his response as curious. Note, too, his bemusement rather than alarm. In "Sparkles from the Wheel" Whitman tells a ghost story in which he imagines himself as a specter who will find himself suddenly and fascinatingly returned to the world after he has passed away.

Instead of feeling like a displaced, solitary, and marginalized person, ${ }^{11}$ he enjoys the experience, which he associates with the experiences of children pleasantly passing time. He specifically "joins a group of children watching." $\mathrm{He}$ has not returned to their youthful stage exactly, but he identifies with them and their watchfulness because he is at present in the childhood stage of his new post-mortem existence. If the narrator is unobtrusive, not inclined "to assume the centrality of his ego," 12 one reason is his alignment with the quiet children. As the insights of the very poem narrated by this ethereal advancedchild indicate, the ghost remembers all that he experienced as a youth, an adult and an old man in his previous life-phase. Equipped with this knowledge, he is young again and off on a different life-adventure.

Something he now understands is why children in his previous life are fascinated by the seemingly insignificant sparks from a grinder's wheel. These youthful observers do not know why such glints of light draw and hold their attention; and when they become adults caught up in the whirl of life's business, they will either forget or devalue such juvenile curiosity. The phantom, however, does recognize the significance of the wheel and its sparkles. $\mathrm{He}$ returns to "this scene and all its belongings" (its implications), and like the children beside him he is "seize[d] and affect[ed]." There is something in particular about the nature of time that his reborn self now delightfully understands.

The focal site of this knowledge is the "whirling" wheel, one of the two central images in this poem narrated by Whitman's imagined ghost of himself. The wheel is a significant image elsewhere in Whitman's verse, with perhaps "The Dalliance of Eagles" (273-274) providing the best indication of its meaning for the poet. In this poem two mating eagles form "a living, fierce, gyrating wheel." This generative wheel ("twain yet one") strikes the poet as a microcosm of the originating cosmic spiral force that unifies everything throughout creation. It is the spiral pattern Transcendentalists learned from by Plato, Vico, Hegel, and Humboldt, among others. It is the spiral pattern replicated 
in the mandala structural design of Walden (1854), in which Thoreau's claims that all life is "great circle-sailing" that unfolds "by an internal industry and expansion." 13

There is, as well, an even more conventional iconography of "the whirling stone" as the determiner of life. A Shakespearean character, for instance, implores Fortune to "smile once more[;] turn thy wheel" (II, ii, 180), and later we learn that the "wheel [has] come full circle" (V, iii, 174) $\cdot{ }^{14}$ Behind Shakespeare's imagery here is a very long tradition, still proverbially available in Whitman's time, of representing fate as a moving wheel of fortune. As numerous medieval pictorial representations and fire-wheel ceremonies indicated, at birth all humans ascend this wheel of life and fall from it at the time of their death.

This long-lived tradition, replete with mystical associations, informs Whitman's image of copulating eagles forming a generative wheel and, as well, his image of a treadle wheel throwing off glints of light as if suggestive of a "creative act." 15 How carefully the poet refers to the "sharp-chinn'd old man." What is it about the "measur'd tread" of the time he keeps at the wheel, we are invited to ponder, that correlates the "sharpening" effects of aging on the man and his activity of "sharpening a great knife"? It is as if the wheel of time, like the treadle wheel in relation to blades, has honed the grinder, readied him for his next application.

The glints, which represent the mystical "copious" generation of human identities from the "whirling" cosmic spiral force, are as important as the wheel to the phantom. Whitman is typically Transcendentalist in revising rather than rejecting the conventional wheel-of-fortune motif. In the traditional iconography of the wheel a person rises and falls, whereas in Whitman's revision every sparkle-self drops and (the poet carefully adds) darts sideways. Specifically, each person is a precious (golden) divine spark whirled off the wheel of life and set in orbital motion around its generative origin. After its brief arc off the stone, each sparkle from the wheel may seem gone because it is no longer visible to the corporeal eye, but it is actually as present as is the invisible phantom narrating the poem. The returned ghost-narrator's own being attests that neither these sparks nor the passage of time is ephemeral. ${ }^{16}$ No life-spark is ever extinguished, but instead spirals outwardly ad infinitum as one completed orbit (lifetime) expands into another. "[T] here is really no death," Whitman writes in "Song of Myself," because "[a]11 goes onward and outward" (3435). Pertinent here, too, is the poet's image of "years that whirl" him ("Quicksand Years," 448) and Thoreau's sense of life as an ever-expansive "great circle-sailing," like rings rippling outward from a stone dropped into a pond.

Having returned to the world as a phantom who has retained everything he has learned in his previous life, the narrator of "Sparkles from the Wheel" now understands why children in the corporeal world are attracted to something so seemingly insignificant as glints from a knife-grinder's wheel. These children intuitively sense the wonder represented in this "golden" activity; they intuit the marvel of their own births. Hence they sit so attentively, as if reverently silent, in distinct contrast to the noisy bustle of the city around them. What they deeply sense without understanding, the phantom comprehends, though he is as yet only in the childhood stage of his new life-circuit. He realizes that all human life is like a spark spun off a generative wheel, a 
precious sparkle that spirals asymptotically outward through successive expanding orbits (lifetimes).

"Sparkles from the Wheel," then, is about time, especially in relation to the afterlife. It depicts each individual life as a ceaseless movement, a whirl of significant motion. It features children, adults, and an old man-the triadic temporal span of the reader's world-but it particularly emphasizes the point of view of a neophyte phantom commencing another orbit of being in the afterlife. This ghost now appreciates that life is an ongoing sequence of spiraling trajectories in which every ending is always a new beginning.

But to what end? Transcendentalist do not say to what purpose. That an abiding divine-like spiral force informs all being is for them a matter of faith based on observation and conviction. This spiral pattern not only configures the nature of an ever-progressive afterlife but also the nature of contemplation. If the destiny of a self-spark is to expand indefinitely from one mode of being to another, like ripples on a pond's surface or the swelling of tree rings, then the life we are living is already a circuit; and so the endeavor to meditate on the divine-like hub of our being, the animating spark at our core, is a form of mental inward circle-sailing. Even in the world as we know it, we are already the product of spiral orbiting, for our mortal being is but one circuit around its originative core. This is why in "When I Read the Book" Whitman images his life as a series of concentric layers - of Ezekielian wheels within wheels, we might say. The poem moves steadily inward in an increasingly subjective search for an elusive generative center. ${ }^{17}$ For Whitman and Transcendentalists generally, this mysterious nucleus of the ringed self is identical with the inexplicable end toward which that self spirals outwardly through expanding concentric modes of being. Or as Emerson cryptically put it: "The near explains the far." 18

University of Texas at Austin

William J. SCHEICK

\section{NOTES}

1 D. H. Lawrence, "Whitman," Walt Whitman, ed. Harold Bloom (New York: Chelsea House, 1985), 17.

2 For example, E. Fred Carlisle, The Uncertain Self: Whitman's Drama of Identity (East Lansing: Michigan State University Press, 1973), 144-151.

3 Vivian R. Pollak, "Death as Repression, Repression as Death: A Reading of Whitman's 'Calamus' Poems," Walt Whitman of Mickle Street: A Centennial Collection, ed. Geoffrey M. Sill (Knoxville: University of Tennessee Press, 1994), 185, 189.

4 Ivan Marki, The Trial of the Poet: An Interpretation of the First Edition of Leaves of Grass (New York: Columbia University Press, 1976), 124.

5 Harold Aspiz, "Death," Walt Whitman: An Encyclopedia, ed. J. R. LeMaster and Donald D. Kummings (New York: Garland, 1998), 166-168.

6 See Ruth Brandon, The Spiritualists: The Passion for the Occult in the Nineteenth and Twentieth Centuries (New York: Knopf, 1983). 
7 M. Jimmie Killingsworth, Whitman's Poetry of the Body: Sexuality, Politics, and the Text (Chapel Hill: North Carolina University Press, 1989), 93-96.

8 William J. Scheick, "The House of Nature in Thoreau's A Week," ESQ: A fournal of the American Renaissance, 20 (2nd Quarter 1974): 111-116.

9 "Whispers of Heavenly Death" and "Song of the Broad-Axe," Leaves of Grass, ed. Sculley Bradley and Harold W. Blodgett (New York: W. W. Norton, 1966), 442, 188. All subsequent quotations from Whitman's verse are drawn from this edition, with page numbers given in parentheses.

10 An overview of the scholarship is provided by Howard Nelson, "Sparkles from the Wheel,"Walt Whitman: An Encyclopedia, 677-678.

11 This suggestion has been made by M. Wynn Thomas, The Lunar Light of Whitman's Poetry (Cambridge: Harvard University Press, 1987), 173.

12 Richard Pascal, "Whitman's 'Sparkles from the Wheel," Walt Whitman Review (March 1982), 23.

13 Henry David Thoreau, Walden and Civil Disobedience, ed. Owen Thomas (New York: W. W. Norton, 1966), 15-16, 211.

14 William Shakespeare, King Lear, ed. George Lyman Kittredge (Boston: Ginn, 1940), $44,112$.

15 James E. Miller, Jr., A Critical Guide to Leaves of Grass (Chicago: University of Chicago Press, 1957), 153.

16 That they are ephemeral is observed by John Snyder, The Dear Love of Man: Tragic and Lyric Communion in Walt Whitman (Mouton: The Hague, 1975), 236-238.

17 William J. Scheick, "The Parenthetical Mode of Whitman's 'When I Read the Book," Walt Whitman Quarterly Review 13 (Spring 1996), 221-224.

18 Ralph Waldo Emerson, "The American Scholar," Selections from Ralph Waldo Emerson, ed. Stephen E. Whicher (Boston: Houghton Mifflin, 1957), 78. 